九州大学学術情報リポジトリ

Kyushu University Institutional Repository

Introducing a Spatial Equilibrium Model under Consideration of a Realistic Differential Tariff System to the Japanese Pork Import Market : Reflecting upon the Impact of the Gate-Price under Perfect Competition

Bergen, Martina

Department of Agricultural Policy and Marketing, University of Hohenheim

Kawaguchi, Tsunemasa

Laboratory of Quantitative Analysis of Agribusiness Organisation, Division of Industrial Organisation of Agribusiness, Department of Agricultural and Resoruce Economics, Faculty of Agriculture, Kyushu University

https://doi.org/10.5109/4609

出版情報: 九州大学大学院農学研究院紀要. 49 (2)，pp.477-496，2004-10-01. Faculty of Agriculture, Kyushu University

バージョン：

権利関係 : 


\title{
Introducing a Spatial Equilibrium Model under Consideration of a Realistic Differential Tariff System to the Japanese Pork Import Market -Reflecting upon the Impact of the Gate-Price under Perfect Competition-
}

\author{
Martina BERGEN ${ }^{1 *}$ and Tsunemasa KAWAGUCHI \\ Laboratory of Quantitative Analysis of Agribusiness Organisation, Division of Industrial \\ Organisation of Agribusiness, Department of Agricultural and Resource Economics, \\ Faculty of Agriculture, Kyushu University, Fukuoka 812-8581, Japan \\ (Received March 12, 2004 and accepted July 13, 2004)
}

\begin{abstract}
In the course of the presently ongoing WTO negotiation round on agriculture several production sectors especially of those markets with a high protection level are submitted to a careful examination for further liberalisation possibilities. The Japanese agricultural sector, which is still being highly protected by domestic support as well as by several border measures, is amongst those markets that are internationally highly criticised. Although Japan has successfully implemented its obligations according to the previous Uruguay Round Agreement there are still complicated protection measures, which impede a further market opening. The so-called gate-price system of the Japanese pork market is amongst those protective measures, which were negotiated on in the Uruguay Round and have ever since proved to be an obstacle to an unhampered pork trade between Japan and its major pork exporters. However, acting as a variable levy it is difficult to integrate the gate-price into spatial equilibrium models. This paper presents one possible method of introducing the gate-price to spatial equilibrium trade models by converting it into an ad valorem tariff equivalent rate.
\end{abstract}

\section{INTRODUCTION}

Japan's pork market represents a highly regulated system, which allows domestic pork farmers to produce at relatively high costs and yet remain sheltered despite a strong competition from the U.S., Canada, and Denmark or geographically close countries such as Taiwan and South Korea. The main reason for high production costs in Japan is related to the fact that fodder for livestock needs to be imported from abroad due to the lack of domestic fodder production. Corresponding to the disadvantage of land scarcity causing lack of fodder production, appropriate production sites allowing for economies of scale is also very rare. Being one of the world's highest industrialised countries wages in Japan are also relatively high. A combination of high labour, land and feed costs results in comparably high pork production costs.

\footnotetext{
${ }^{1}$ Department of Agricultural Policy and Marketing, University of Hohenheim, D-70593 Stuttgart. Research Student, Laboratory of Agricultural Economics, Division of International Agricultural Resource Economics and Business Administration, Department of Agricultural and Resource Economics, Graduate School of Bioresource and Bioenvironmental Sciences, Kyushu University, Fukuoka 812-8581, Japan

* Corresponding author (E-mail: martinabergen@web.de)
} 
Table 1. Pork operating production costs compared, 2002.

Unit: US $\$ / 100 \mathrm{~kg}$ live weight

\begin{tabular}{lccccccc}
\hline & Japan $^{1}$ & Canada $^{2}$ & U.S. $^{3}$ & Denmark $^{4}$ & Korea $^{5}$ & Mexico $^{6}$ & EU15 $^{7}$ \\
\hline Factor Cost & 169.60 & 88.30 & 76.47 & 97.76 & 106.78 & & \\
Incl. Feed Cost & 125.27 & 66.63 & 44.92 & 39.95 & 54.95 & & \\
Labour Cost & 34.92 & 11.10 & 11.69 & n.a. & 15.67 & & \\
\hline Total & 204.52 & 99.40 & 88.16 & 105.66 & 120.96 & n.a. & 158.42 \\
\hline
\end{tabular}

Source: ${ }^{1} \mathrm{MAFF}$, Livestock production cost annual report, 2003; ${ }^{2} \mathrm{Guidelines}$ for estimating Swine Farrow-Finish Costs 2003, www.gov.mb.ca. (26.02.04); ${ }^{3}$ Farm Business Management 06.08.02, www.farmdoc.uiuc.edu (2004/01/07); ${ }^{4}$ Danish Institute of Agricultural and Fisheries economics, 1995; ${ }^{5}$ Estimated by KIM JAKYUNG, Kyushu University, Japan for 2001; ${ }^{7}$ AgrarEurope, 28.11.03.

Note: Exchange Rate: 119.60 Yen/US\$, 1.34 Can\$/US\$, Crone/US\$, 1282.05Won/US\$, 0.94661 Euro/US\$; Data for Japan refer to per $100 \mathrm{~kg}$ live weight produced in 2002, data for Canada refer to break-even price carcass weight in 2003, U.S. data for hundred kg produced for 2001 , Korean data refer to 2001.

The author did not research in detail on the formation of the production costs. However, it shall serve as a trend only.

In addition, domestic production capacity does not meet the volume of pork domestically demanded so that imports account for an inevitable source of Japan's pork consumption. It should however not go unnoticed, that only with the availability of inexpensive imported meat has the ways of Japanese people's diet altered. The availability of imported meat, however, has been supported by former reductions in trade restrictions such as the first liberalisation of the pork market in 1971.

However, not only with respect to the recently ongoing WTO negotiations on agriculture but also under consideration of the current decade trend characterised by the idea of globalisation, discussions on Japan's general agricultural protection system itself have

Table 2. Pork consumption and supply in Japan.

\begin{tabular}{|c|c|c|c|c|c|c|c|}
\hline \multirow[t]{2}{*}{ Year } & \multirow{2}{*}{$\begin{array}{l}\text { Total Supply } \\
\text { and Demand }\end{array}$} & \multicolumn{3}{|c|}{$\begin{array}{c}\text { Share of total } \\
\text { Meat consumption }\end{array}$} & \multirow{2}{*}{$\begin{array}{l}\text { Domestic } \\
\text { Production }\end{array}$} & \multirow{2}{*}{$\begin{array}{c}\text { Self-sufficiency } \\
\text { rate }\end{array}$} & \multirow{2}{*}{$\begin{array}{l}\text { Total import } \\
\text { volume }\end{array}$} \\
\hline & & Pork & Beef & Chicken & & & \\
\hline 1990 & 204 & 41 & 22 & 34 & 156 & 76 & 48.8 \\
\hline 1991 & 207 & 41 & 22 & 34 & 148 & 72 & 63.1 \\
\hline 1992 & 212 & 41 & 23 & 34 & 143 & 68 & 66.7 \\
\hline 1993 & 209 & 39 & 25 & 33 & 144 & 69 & 65.0 \\
\hline 1994 & 209 & 39 & 27 & 39 & 139 & 66 & 72.4 \\
\hline 1995 & 215 & 38 & 27 & 32 & 132 & 61 & 77.2 \\
\hline 1996 & 220 & 40 & 26 & 32 & 127 & 58 & 93.27 \\
\hline 1997 & 201 & 38 & 26 & 33 & 128 & 64 & 73.07 \\
\hline 1998 & 201 & 38 & 28 & 33 & 129 & 64 & 72.07 \\
\hline 1999 & 213 & 39 & 28 & 32 & 128 & 60 & 85.69 \\
\hline 2000 & 220 & 39 & 23 & 32 & 127 & 58 & 92.91 \\
\hline
\end{tabular}

Source: Domestic Livestock annual, various edition (Ministry of Agriculture, Fishery and Forestry, Japan). 
been relumed. Some further events such as the nearly failed attempt on a Japanese-Mexican Free Trade Agreement have directed not only international but also domestic attentions to the highly protected Japanese pork sector.

The Japanese pork market is protected in two ways, which are directly interlined. While subsidies are being paid through prefectural governments according to a complicated system, which requires detailed and individual research, a differential tariff system provides the basis for these payments. The Japanese differential tariff system for pork-

Table 3. Support by product in Japan.

Unit: billion Yen

\begin{tabular}{cccccrr}
\hline According to & Pork & Beef & Poultry & Dairy & Rice & Wheat \\
\hline AMS $^{1}$ & 265 & 168 & n.a. & 142 & 0 & 69 \\
PSE $^{2}$ & 258 & 218 & 24 & 584 & 2191 & 84
\end{tabular}

Source: OECD Database, 1985-2002, Ministry of Agriculture, Forestry and Fisheries of Japan.

Note: ${ }^{1}$ Aggregate Measure of Support calculated by the Japanese government as part of its report to the WTO on domestic support for agriculture; for 1999 last year available.

${ }^{2}$ Producer Support Estimated by the OECD, also based on the concept of support for market prices; for 1999 in order to compare.

Table 4. Pork Producer Support Estimate by country, 2002.

Unit: Mill. US\$, \%

\begin{tabular}{lrcrrr}
\hline & Japan & United States & Canada & EU 15 & Mexico \\
\hline Total PSE in US\$ & 2111 & 415 & 156 & 6395 & 392 \\
Percentage PSE & 54 & 5 & 7 & 26 & 24 \\
\hline
\end{tabular}

Source: OECD Database, 1985-2002.

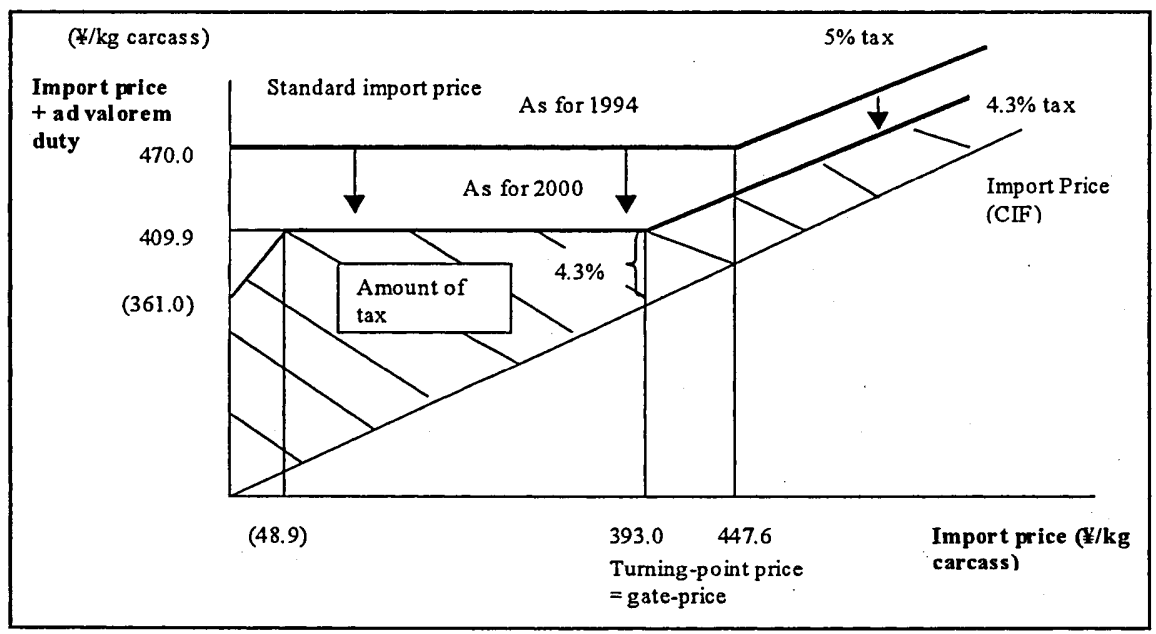

Fig. 1. Japan's pork gate-price system. 
or more precisely meat of swine- constitutes of a relatively low ad valorem tariff of $4.3 \%$. In addition, a so-called gate-price system confronts imports at the border. It imposes a minimum import price on pork shipments. For shipments valued below the minimum price, importers have to pay the difference between the shipment's value and the minimum price. Hence, the system taxes the importation of lower-valued pork cuts.

Related to the gate-price system the so-called emergency import safeguard measures are automatically invoked whenever import volume for a particular fiscal quarter exceed the average for the same quarter of the past three years by more than $19 \%$. The safeguard then raises the gate-price from $524 \mathrm{Yen} / \mathrm{kg}$ to $653 \mathrm{Yen} / \mathrm{kg}$ for cuts of meat of swine, and from $393 \mathrm{Yen} / \mathrm{kg}$ to $489 \mathrm{Yen} / \mathrm{kg}$ for carcass meat of swine.

The effect of the gate-price system, particularly in case the safeguard is triggered, is a thorn especially in the side of major pork exporters to Japan. Major pork exporters to Japan include the United States, Canada, the EU 15 basically represented by Denmark, and recently Mexico.

Table 5. Pork imports to Japan, volume and value base.

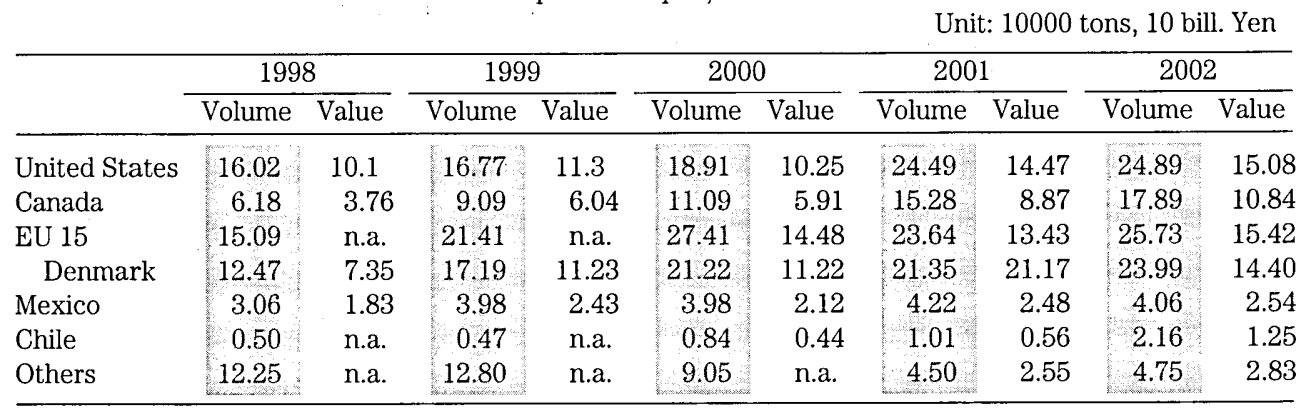

Source: The Meat Statistics in Japan, various editions, MAFF Agricultural production bureau and JETRO, Agro-Trade Book, various editions. MAFF, Livestock Division, Press Release.

And although opinions on the gate-price system itself differ in detail among the exporters it has been stated clearly by the U.S. and Canadian side that an amendment of the system is necessary in order to do justice to an agricultural market liberalisation. An elimination of the gate-price system is requested.

The objective of this research is to evaluate in a first step how trade flows in pork change in case the gate-price was abolished. The following scenarios are dealt with by applying the below-introduced spatial equilibrium trade model on international trade as it has been developed by our research team (Professor Kawaguchi and Mr. Hideyuki Kano, Kyushu University, Japan, Martina Bergen, University of Hohenheim, Germany).

1. Gate-price system will be abolished, import tariff remains at 4.3 percent

2. Import tariff will be reduced/ abolished, gate-price will remain

3. Import tariff will be reduced/abolished as well as the gate-price

4. Safeguard is triggered, which raises the gate-price 


\section{THEORETICAL MODEL AND APPLICATION}

An alternative approach to purely commodity modelling introduces spatial and interregional efficiency in commodity production, distribution and utilisation. The recognition of the transportation of commodities and its related costs between regions extends the commodity modelling approach to spatial analysis. The class of models known as spatial price equilibrium models uses a detailed transport matrix in order to reflect on realistic world trade flows. In the spatial price equilibrium problem, one seeks to compute the commodity supply prices, demand prices, and trade flows satisfying the equilibrium condition that the demand price is equal to the supply price plus the cost of transportation, if there is trade between the pair of supply and demand markets.

There are presently various algorithms that have been developed for the solution of spatial price equilibrium problems. While ENKE (1951) established the connection between spatial price equilibrium problems and electronic circuit networks and showed that this analogue could then be used to compute the spatial prices and commodity flows, SAMUELson (1952) and TAKAYAma and Judge (1964a, b, 1971) showed that the prices and commodity flows satisfying the spatial price equilibrium conditions could be determined by solving an extremal problem, in other words, a mathematical programming problem (NAGURNEY, 1993). TAKAYAMA and JUDGE have devised linear and quadratic programming algorithms for solving these problems when the supply-and-demand functions are linear curves. The model then operates such that transportation costs are minimised by allowing commodities to transfer until demand equals supply in every spatially separated markets. The cost minimisation process is established by maximisation of the objective function. The constraint relations reflect conditions that regional consumption cannot exceed the total shipment to a region and that the total shipments from a region cannot exceed the total quantity available for shipment. A further relation assures the lack of negative shipments.

TAKAYAMA and Judge (1971), and later on also NAGURNEY et al. (1993) have further developed spatial equilibrium models, which recognise tariffs as an additional constraint. Later SHONO and KAWAGUCHI (1999a, b) introduced a spatial equilibrium model for international trade, which introduces realistic tariffs in that it emphasises the existence of a tariff-quota system, which was not considered in the previous models. In reality, although of homogenous quality, merchandised goods are divided into a primary and a secondary market. At the primary market goods can be imported at a low-level tax rate up to a fixed quantity (Minimum access, current access quantity). Exceeding this quantity level, goods have to be imported at a high-level tax rate to the secondary market. Secondly, apart from the existing quantity-based tariff, the so-called specific tariff, one also finds a price-based tariff, the so-called ad valorem tariff, which are further often combined to a third compound tariff.

SHONO and KAWAGUCHI (2000) have further extended the model by introducing export quota and minimum export prices, and later export subsidies under perfect competition as well as under imperfectly competitive conditions (SHONO et al., 2001). The gate-price system has not yet been explicitly integrated into the model.

Based on the model introduced by our research team, the gate-price is integrated as a further restriction by converting it into an ad valorem tariff equivalent rate following the 
mathematical interrelation:

$$
f(C I F)=\left\{\begin{array}{lr}
(G P-C I F) / C I F=(G P / C I F-1), & \text { when }(G P-C I F) / C I F \geq \delta \\
\delta, & \text { when }(G P-C I F) / C I F<\delta
\end{array}\right.
$$

Where $\delta$ is some specified ad valorem tariff rate.

The general idea of the model is demonstrated through its application to the Japanese pork market. However, a few basic principles need to be given in advance.

In order to apply the spatial equilibrium model of international trade among $n(n \geq 2)$ countries the following notations are used. If there is no specific definition, $i, j$ refers to any integer from 1 to $n$.

a) In correspondence to the tariff-quota system mentioned above, we consider the markets of all countries as two different tariff markets, the primary and secondary market with a corresponding primary and secondary tariff rate.

b) $C A_{j}$ represents the current access quantity in the primary market of country $j$. With regard to exports from country $i$ to country $j$ the compound tariff composition of the importing country $j$ is shown in Table 6. In addition, the compound tariff rates as shown in Figure 2 generally result in the following relation $\alpha_{i j} \leq a_{i j}$ (Price), $\beta_{i j} \leq b_{i j}$

Table 6. Compound tariff system of country j for imports from country i.

\begin{tabular}{lcc}
\hline & Primary market & Secondary market \\
\hline Price-based tariff rate & $\alpha_{\mathrm{ij}}$ & $\mathrm{a}_{\mathrm{ij}}$ \\
Quantity-based tariff rate & $\beta_{\mathrm{ij}}$ & $\mathrm{b}_{\mathrm{ij}}$ \\
\hline
\end{tabular}

Source: SHONO and KAWAGUCHI (1999a).

Tax rate

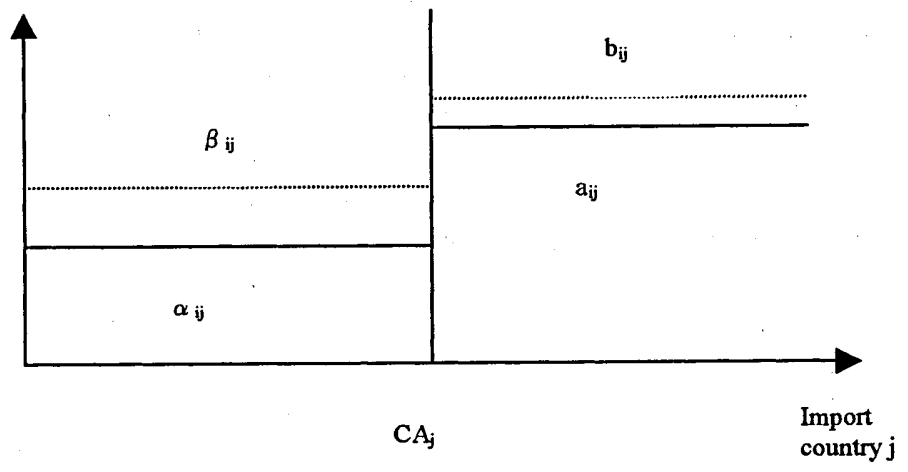

Remark: the tax rate level shown in the solid as well as the perforate line exist in various pairs of countries, and in general the relation $\alpha_{\mathrm{ij}}<\mathrm{a}_{\mathrm{ij}}, \beta_{\mathrm{ii}}<\mathrm{b}_{\mathrm{ii}}$ is solely to be found. In this figure there is no special meaning to the larger or smaller size relation of $\alpha$ and $\beta$ (or a and $b$ ).

Fig. 2. Compound tariff in two separately regarded markets. 
(Quantity), with $\alpha, \beta$ representing the primary market, and $\mathrm{a}, \mathrm{b}$ the secondary market.

As a formality, domestic supply within country $i$ is also considered to be an export to the primary market of country $i$. Hence, $\alpha_{i i}=\beta_{i i}=0$. However, domestic supply is not considered to be part of the general import quantity. As a formal prerequisite $a_{i \mathrm{i}}$ and $b_{\mathrm{i}}$ for imports are adjusted to prohibitive values at a high level by which an import to the secondary market becomes impossible.

c) Quantity is marked for all trading countries as shown below in Table 7. For formality reasons the quantity traded from country $i$ to country $i$ in the secondary market is marked by $X$ sii, but its value equals 0 . Further $D j=D 1 j+D 2 j$ introduces total demand in country $j$, whereas in country $i, S i$ defines the supply quantity, and in country $j, D j$ marks the demand quantity.

e) We use PSi to refer to the production price in country $i$, and $P D j$ to represent the market price in country $j$ respectively. Tij reflex the transportation costs (more generally transaction costs) per unit traded good from country $i$ to country $j$. Insurance premium per unit for export from country $i$ to $j$ is defined as $I i j$.

The following function shows the resulting linear supply function in country $i$ :

$$
S i=-\mu i+\eta i(P S i), \quad \text { (generally } \eta i>0 \text { ) }
$$

Its adverse function is given as:

$$
P S i=(u i / \eta i)+(1 / \eta i) S i
$$

In addition, in country $j$ the linear demand function is as follows:

$$
D j=\gamma j-\lambda j(P D j), \quad \text { (generally } r j>0, \lambda j>0 \text { ) }
$$

Its adverse function is given as:

$$
P D j=(\gamma j / \lambda j)-(1 / \lambda j) D j
$$

Table 7. Traded quantity and supply and demand quantity for all countries (n).

\begin{tabular}{ccccccccccc}
\hline Importing country/market & 1 & 2 & $\ldots$ & $\mathrm{n}$ & 1 & 2 & $\ldots$ & $\mathrm{n}$ & Sum \\
\cline { 2 - 9 } Exporting country & \multicolumn{1}{c}{ Primary market } & \multicolumn{1}{c}{ Secondary market } \\
1 & $\mathrm{X} 11$ & X12 & $\ldots$ & X1n & Xs11 & Xs12 & $\ldots$ & Xs1n & S1 \\
2 & X21 & X22 & $\ldots$ & X2n & Xs21 & Xs22 & $\ldots$ & Xs2n & S2 \\
$\vdots$ & $\vdots$ & $\vdots$ & $\vdots$ & $\vdots$ & $\vdots$ & $\vdots$ & $\vdots$ & $\vdots$ & $\vdots$ \\
$n$ & Xn1 & Xn2 & $\ldots$ & Xnn & Xsn1 & Xsn2 & $\ldots$ & Xsnn & Sn \\
Sum & D11 & D12 & $\ldots$ & D1n & D21 & D22 & $\ldots$ & D2n & & \\
\hline
\end{tabular}

Two basic principles are used for introducing realistic and differential tariffs to the spatial equilibrium model of international trade.

First, by analyzing two separated markets one has to consider the shadow price, which is the price for the advantageous right to sell goods to the primary market on preferential tariff rate conditions. Export to the primary market, which is mainly characterized by an import restriction, is limited. At the same time export to the secondary 
market, where there is no domestic supply, is not limited. By introducing the shadow price these two separate markets can be mathematically analyzed under the same marginal framework.

Secondly, in order to meet the requirements for the equilibrium solution of the spatial equilibrium model, a linear complementarity problem is developed, which solves the equilibrium problem. This particular LCP solution cannot be considered the optimal point for any maximization problem. Therefore, the equilibrium problem at hand cannot be solved by traditional maximization methods, which were used to solve many traditional spatial equilibrium problems ${ }^{2}$.

Equilibrium conditions in this context refer to equilibrium conditions under perfect market competition. Producers and consumers are assumed to behave as price-takers with regard to the fact that market prices are given. Further, a static equilibrium is used to analyze the problems of how each country decides on the supply quantity to a specific market, and which price is agreed on at this market. By seeking the value of every variable, which meets all the requirements for the equilibrium simultaneously, the equilibrium conditions in the case of $n=3$ can be explained as follows:

a) Equilibrium conditions of markets

Demand quantity in country $j$ does not exceed the sum of the shipped quantity from all countries including country $j$ to country $j$, and the both are equal if the market price $P D j$ is positive. They can differ if and only if $P D j$ equals 0 .

$$
\begin{aligned}
& \gamma j-\lambda j P D j \leq X 1 j+X 2 j+X 3 j+X s 1 j+X s 2 j+X s 3 j \\
& (-\gamma j+\lambda j P D j+X 1 j+X 2 j+X 3 j+X s 1 j+X s 2 j+X s 3 j) P D j=0
\end{aligned} \quad(j=1,2,3)
$$

\section{b) Equilibrium conditions of producers}

The sum of the shipped quantity from country $i$ to all countries does not exceed the supply quantity in country $i$, both are equal if the production price PSi is positive. They can differ if and only if PSi equals 0 .

$$
\begin{aligned}
& X i 1+X i 2+X i 3+X s i 1+X s i 2+X s i 3 \leq-\mu i+\eta i P S i \quad(i=1,2,3) \\
& (-\mu i+n i P S i-X i 1-X i 2-X i 3-X s i 1-X s i 2-X s i 3) P S i=0
\end{aligned}
$$

\section{c) Equilibrium conditions of Xij}

Deducting the sum of the compound tariff of the primary market $\beta i j+\alpha i j(P S i+$ $T i j+I i j)$, the unit transportation costs $T i j$, unit insurance costs $I i j$ and the shadow price $S P j$ from the market price $P D j$ in country $j$, one calculates the value of marginal revenue (MR) of the traded good in the producing country $i$ in case of shipment to the concerned market $j$. This MR value does not exceed the production price PSi, which means the marginal income per unit is smaller than or equal the production price, and if smaller then $X i j$ equals 0 . Xij can be positive if and only if this MR is equal to PSi. After a simple transformation this relation is expressed by the following formula (in case of $i=j$, the term $S P j /(1+\alpha i j)$ should be deleted.)

\footnotetext{
${ }^{2}$ For further information on the existence of a solution to LCP in Spatial Equilibrium Model of International Trade and its Algorithm see KAWAGUCHI and SHONO (2000).
} 


$$
\begin{aligned}
& P D j /(1+\alpha i j)-P S i-S P j /(1+\alpha i j) \leq T i j+I i j+\beta i j /(1+\alpha i j) \quad(j=1,2,3 i=1,2,3) \\
& {[T i j+I i j+\beta i j /(1+\alpha i j)-P D j /(1+\alpha i j)+P S i+S P j /(1+\alpha i j)] X i j=0}
\end{aligned}
$$

\section{d) Equilibrium conditions of Xsij}

The marginal revenue (MR), in country $i$ in the case of shipping to the relevant market $j$, is calculated by deducting the compound tariff bij+aij $(P S i+T i j+I i j)$, unit transportation costs $T i j$ and unit insurance costs $I i j$ from county j's market price $P D j$. It does not exceed the production prices $P S i$ and if MR is smaller than the production price $P S i$, then $X s i j$ equals 0 . Xsij can be positive if and only if these two are equal.

This is expressed in the following way:

$$
\begin{aligned}
& P D j /(1+\mathrm{a} i j)-P S i \leq T i j+I i j+\mathrm{b} i j /(1+\mathrm{a} i j) \\
& {[T i j+I i j+\mathrm{b} i j /(1+\mathrm{a} i j)-P D j /(1+\mathrm{a} i j)+P S i] X s i j=0}
\end{aligned} \quad(j=1,2,3 i=1,2,3)
$$

\section{e) Equilibrium condition of $S P j$}

The total import quantity to the primary market of country $j$ does not exceed the current access quantity $C A j$ of the relevant market. In case the total import quantity is lower than the current access quantity, the shadow price $S P j$ of the relevant market equals 0 .

The shadow price $S P j$ can be positive if and only if these two are equal.

$$
\begin{aligned}
& X 1 j+X 2 j+X 3 j-X j j \leq C A j \quad(j=1,2,3) \\
& (C A j-X 1 j-X 2 j-X 3 j+X j j) S P j=0
\end{aligned}
$$

The above explanation of equilibrium conditions in perfect market competition can be also expressed in 27 steps of equations and inequalities. First, slack variables are introduced in each of these 27 inequalities, and then the equilibrium conditions are transformed in the following way. Note, all variables including slack variables are assumed to be non-negative. The following equations are subject to $n=3$, as an example.

Equilibrium conditions of markets

1. $V 1=-\gamma 1+\lambda 1 P D 1+X 11+X 21+X 31+X s 11+X s 21+X s 31$

2. $V 2=-\gamma 2+\lambda 2 P D 2+X 12+X 22+X 32+X s 12+X s 22+X s 32$

$P D 1 \mathrm{V1}=0$

3. $V 3=-\gamma 3+\lambda 3 P D 3+X 13+X 23+X 33+X s 13+X s 23+X s 33$

$P D 2$ V2 $=0$

$P D 3 V 3=0$

Equilibrium conditions of producers
4. $v 1=-\mu 1+\eta 1 P S 1-X 11-X 12-X 13-X s 11-X s 12-X s 13$
5. $v 2=-\mu 2+\eta 2 P S 2-X 21-X 22-X 23-X s 21-X s 22-X s 23$
$P S 1 v 1=0$
$P S 2 v 2=0$
$6 . v 3=-\mu 3+\eta 3 P S 3-X 31-X 32-X 33-X s 31-X s 32-X s 33$
$P S 3 v 3=0$

Equilibrium conditions of Xij

7. $Y 11=T 11+I 11+\beta 11 /(1+\alpha 11)-P D 1 /(1+\alpha 11)+P S 1$

$X 11 Y 11=0$

8. $Y 21=T 21+121+\beta 21 /(1+\alpha 21)-P D 1 /(1+\alpha 21)+P S 2+S P 1 /(1+\alpha 21) \quad X 21 Y 21=0$

9. $Y 31=T 31+131+\beta 31 /(1+\alpha 31)-P D 1 /(1+\alpha 31)+P S 3+S P 1 /(1+\alpha 31) \quad X 31 Y 31=0$

10. $Y 12=T 12+I 12+\beta 12 /(1+\alpha 12)-P D 2 /(1+\alpha 12)+P S 1+S P 2 /(1+\alpha 12) \quad X 12 Y 12=0$ 
$\begin{array}{ll}\text { 11. Y22 }=T 22+122+\beta 22 /(1+\alpha 22)-P D 2 /(1+\alpha 22)+P S 2 & X 22 Y 22=0 \\ \text { 12. Y32 }=T 32+132+\beta 32 /(1+\alpha 32)-P D 2 /(1+\alpha 32)+P S 3+S P 2 /(1+\alpha 32) & X 32 Y 32=0 \\ 13 . Y 13=T 13+I 13+\beta 13 /(1+\alpha 13)-P D 3 /(1+\alpha 13)+P S 1+S P 3 /(1+\alpha 13) & X 13 Y 13=0 \\ 14 . Y 23=T 23+123+\beta 23 /(1+\alpha 23)-P D 3 /(1+\alpha 23)+P S 2+S P 3 /(1+\alpha 23) & X 23 Y 23=0 \\ 15 . Y 33=T 33+133+\beta 33 /(1+\alpha 33)-P D 3 /(1+\alpha 33)+P S 3 & X 33 Y 33=0\end{array}$

Equilibrium conditions of Xsij.

16. $\mathrm{Ys} 11=T 11+I 11+\mathrm{b} 11 /(1+\mathrm{a} 11)-P D 1 /(1+\mathrm{a} 11)+P S 1$

$X s 11 Y s 11=0$

17. $Y S 21=T 21+I 21+\mathrm{b} 21 /(1+\mathrm{a} 21)-P D 1 /(1+\mathrm{a} 21)+P S 2$

$X s 21 Y s 21=0$

18. $Y$ S31 $=T 31+I 31+\mathrm{b} 31 /(1+\mathrm{a} 31)-P D 1 /(1+\mathrm{a} 31)+P S 3$

$X s 31 Y$ S31 $=0$

19. $Y s 12=T 12+I 12+\mathrm{b} 12 /(1+\mathrm{a} 12)-P D 2 /(1+\mathrm{a} 12)+P S 1$

$X s 12 Y s 12=0$

20. $Y s 22=T 22+I 22+\mathrm{b} 22 /(1+\mathrm{a} 22)-P D 2 /(1+\mathrm{a} 22)+P S 2$

$X s 22 Y s 22=0$

21. $Y S 32=T 32+132+\mathrm{b} 32 /(1+\mathrm{a} 32)-P D 2 /(1+\mathrm{a} 32)+P S 3$

$X s 32 Y s 32=0$

22. $Y s 13=T 13+I 13+\mathrm{b} 13 /(1+\mathrm{a} 13)-P D 3 /(1+\mathrm{a} 13)+P S 1$

$X s 13 Y s 13=0$

23. $Y S 23=T 23+I 23+\mathrm{b} 23 /(1+\mathrm{a} 23)-P D 3 /(1+\mathrm{a} 23)+P S 2$

$X s 23 Y$ S23 $=0$

24. $Y S 33=T 33+133+\mathrm{b} 33 /(1+\mathrm{a} 33)-P D 3 /(1+\mathrm{a} 33)+P S 3$

$X s 33 Y s 33=0$

Equilibrium conditions of $S P j$
25. $Z 1=C A 1-X 21-X 31$
$S P 1 Z 1=0$
26. $Z 2=C A 2-X 12-X 32$
$S P 2 Z 2=0$
$27 . Z 3=C A 3-X 13-X 23$
$S P 3 Z 3=0$

Further, because taxation regulations usually do not count for domestic supply $X 11$, X22, X33 tariff rates $\alpha 11=\alpha 22=\alpha 33, \beta 11=\beta 22=\beta 33$ generally become 0 . Also, if at the primary market of country $j$ a tariff, as it is the case in the markets of Japan, only exists as ad valorem tariff, $\beta i j$ becomes 0 .

Further, if the requirements of the above 27 mathematical expressions ${ }^{3}$ are presented in a matrix and vector symbol, it is clear that the problem can be specified as the problem to find the value of vectors $\mathbf{P}$ and $\mathbf{W}$ that meet the requirements of $\boldsymbol{W}=\boldsymbol{A P}+\boldsymbol{B}$ and $\boldsymbol{W}^{\boldsymbol{r}}$ $\boldsymbol{P}=\mathbf{0}$, as suggested by the particular LCP problem. In other words, the problem can be specified as a linear complementarity problem. Therefore, if the linear complementarity problem can be solved, the equilibrium solution can be found.

With the introduction of the gate-price and corresponding equivalent tariff rate function $\mathrm{f}(\mathrm{CIF})$, the basic equation are extended. However, although the new model now embeds a non-linear complementarity problem, the non-linear equations can be solved by solving iteratively a series of linear complementarity problem. This solution method is presented in detail by two members of our research team (KANO and KAWAGUCHI, 2004a, b, c).

Five pork-trading countries and areas (EU15 ${ }^{4}$, U.S., Canada, Mexico and Japan) are considered. Sharing about 85 percent of world total pork exports and being the major suppliers to the Japanese market, each of these countries may be assumed to behave as a

3 In the case of $n=5$ there are 65 .

4 Represented by Denmark. In a further research step, EU25 will be alternatively taken into consideration. 
Cournot player and hence the international pork market may be imperfectly competitive ${ }^{5}$. Table 8 shows domestic trade and support policies for pork in each country involved in this research. Tariff rates and tariff-quotas represent levels in 2000 committed by each country under the WTO agreement.

Table 8. Trade and Domestic Support Policies in Each Country and Area. Unit: NC per mt carcass weight equivalent, \%, mt

\begin{tabular}{|c|c|c|c|c|c|c|c|c|}
\hline \multirow{4}{*}{$\begin{array}{c}\text { Country } \\
\text { and } \\
\text { Area }\end{array}$} & \multicolumn{8}{|c|}{ Trade Policies } \\
\hline & \multicolumn{4}{|c|}{ In-quota import Market } & \multicolumn{2}{|c|}{ Over-quota Import Market } & \multirow{3}{*}{$\begin{array}{ll}\text { Specific } & U \\
\text { Export } & \\
\text { Subsidy } & \end{array}$} & \multirow{3}{*}{$\begin{array}{l}\text { Upper limit of } \\
\text { subsidised } \\
\text { Exports }\end{array}$} \\
\hline & Specific & Ad valorem & $2^{\text {nd }}$. & Tariff-Rate & Specific & Ad valorem & & \\
\hline & Duty & Tariff & Specific & Quota & Duty & Tariff & & \\
\hline $\begin{array}{l}\text { Japan } \\
\text { (Yen) }\end{array}$ & 0 & 4.3 & $\begin{array}{l}(393000 \\
\mathrm{CIF}) / \mathrm{CIF}\end{array}$ & No & Not existent & Not existent & 0 & 0 \\
\hline U.S. (\$) & 0 & 0 & 0 & No & Not existent & Not existent & 0 & 0 \\
\hline $\begin{array}{l}\text { EU } 15 \\
\text { (Euro) }\end{array}$ & $467-867$ & 0 & 0 & 7000 & Not existent & Not existent & In special cases & 0 \\
\hline EU 25 & n.a. & n.a. & n.a. & n.a. & n.a. & Not existent & n.a. & n.a. \\
\hline Canada & 0 & 0 & 0 & No & Not existent & Not existent & No & 0 \\
\hline Mexico & 0 & 45 & 0 & No & Not existent & Not existent & 0 & 0 \\
\hline
\end{tabular}

Source: USDA, Economic Research Service. NC: National Currency.

Note: Mexico: Bound tariff lowered from 50\% to 45\%, 1995-2004. Applied Tariff was 20\% in 2002. Tariff for imports from U.S. and Canada is zero. Special safeguard provisions were put in place to limit import surges.

Japan: Tariff lowered from $5 \%$ to $4.3 \%, 1995-2000$. Gate-price lowered from 612 to 524 Yen $/ \mathrm{kg}$ for cut meat, 460 to $393 \mathrm{Yen} / \mathrm{kg}$ for carcasses, and 1038 to $898 \mathrm{Yen} / \mathrm{kg}$ for processed products, 1995-2000. Special safeguard provisions were put in place to limit import surges.

EU15: Duty is sum of ad valorem and specific tariffs. Ad valorem tariff ceiling on meat lowered from $3 \%$ to zero, 1995-2000. Additional specific tariffs lowered from range of 728-1358 ECU/ton in 1995 to range of $467-869 \mathrm{ECU} / \mathrm{ton}, 2000$. Tariff rate quota of 7,000 tons for loins and bellies.

Canada: zero.

United States: Tariffs on cuts specially prepared for retail lowered from 2.2 cents $/ \mathrm{kg}$ to 1.4 cents $/ \mathrm{kg}$, 1995-2000. Aside from these cuts, tariffs are zero.

Aggregated demand functions are specified in a linear form for simplicity reason. Following this decision, it is assumed that demand for pork must be price-elastic in all markets. However, it is also possible to adjust the model and apply it for the case of non-linear demand and supply functions by simply using a series of revised new tangent lines of the non-linear functions instead of the iterative use of the originally fixed line. The special case of an exponential function is additionally presented in this paper. The details of this so-called Newton's method will be shown in our next paper.

Wholesale prices on a carcass weight equivalent basis are used as market prices for calculating the demand functions. Aggregated demand functions are calculated using long-run price elasticities estimated by OHGA and YANAGISHIMA (1995).

Producer prices, deflating by implicit deflators, are used as marginal cost in each

${ }^{5}$ Studies on this case will be conducted in the near future, and in this paper we study on the case of perfectly competitive markets. 
country. Inverse marginal cost functions are estimated using long-run elasticities estimated by OHGA and YANAGISHIMA (1995). However, in the case of Mexico the supply function needed to be adjusted. Currency exchange rate fluctuations and the impact of the NAFTA had to be taken into further consideration.

Table 9. Linear Demand and Marginal Cost Function in each country.

Unit: US\$/ton; 1000 ton carcass weight

\begin{tabular}{|c|c|c|c|c|}
\hline \multirow[t]{2}{*}{ Country } & \multicolumn{2}{|c|}{ Demand Function } & \multicolumn{2}{|c|}{ Supply Function } \\
\hline & $\begin{array}{l}\text { Aggregated Demand } \\
\text { Function }\end{array}$ & Price Elasticity & $\begin{array}{l}\text { Inverse Marginal Cost } \\
\text { Function }\end{array}$ & Price Elasticity \\
\hline Japan & $\mathrm{q}_{\mathrm{D}}=4274.49-0.5203 \mathrm{P}_{\mathrm{D}}$ & -0.950 & $\mathrm{q}_{\mathrm{s}}=209.43+0.2943 \mathrm{P}_{\mathrm{s}}$ & 0.83 \\
\hline United States & $\mathrm{q}_{\mathrm{D}}=15592.38-6.1640 \mathrm{P}_{\mathrm{D}}$ & -0.860 & $\mathrm{q}_{\mathrm{s}}=-869.11+8.0799 \mathrm{P}_{\mathrm{s}}$ & 1.1 \\
\hline Canada & $\mathrm{q}_{\mathrm{D}}=2021.82-0.9012 \mathrm{P}_{\mathrm{D}}$ & -0.860 & $\mathrm{q}_{\mathrm{s}}=-864.57+2.4965 \mathrm{P}_{\mathrm{s}}$ & 1.5 \\
\hline Denmark & $\mathrm{q}_{\mathrm{D}}=606.60-0.2020 \mathrm{P}_{\mathrm{D}}$ & -0.800 & $\mathrm{q}_{\mathrm{s}}=171.60+1.2638 \mathrm{P}_{\mathrm{s}}$ & 0.9 \\
\hline Mexico & $\mathrm{q}_{\mathrm{D}}=1298-0.0 \mathrm{P}_{\mathrm{D}}$ & 0.000 & $\mathrm{q}_{\mathrm{s}}=1065+0.0 \mathrm{P}_{\mathrm{s}}$ & 0.55 \\
\hline
\end{tabular}

Sources: Price elasticity from OHGA and YANAGISHIMA (1995).

Note: In the case of Mexico, supply functions are adjusted; in the case of Denmark price elasticities are assumed to be the same as in the EU12.

Table 10. Exponential Demand and Marginal Cost Function in each country.

Unit: US\$/ton; 1000 ton carcass weight

\begin{tabular}{llcll}
\hline Country & \multicolumn{2}{c}{ Demand Function } & \multicolumn{2}{c}{ Supply Function } \\
& $\begin{array}{c}\text { Aggregated Demand } \\
\text { Function }\end{array}$ & Price Elasticity & $\begin{array}{c}\text { Inverse Marginal Cost } \\
\text { Function }\end{array}$ & Price Elasticity \\
\hline Japan & $\mathrm{q}_{\mathrm{D}}=5794997.6176\left(\mathrm{P}_{\mathrm{D}}\right)^{-0.95}$ & -0.950 & $\mathrm{q}_{\mathrm{s}}=1.4180\left(\mathrm{P}_{\mathrm{S}}\right)^{0.83}$ & 0.83 \\
United States & $\mathrm{q}_{\mathrm{D}}=3646797.0551\left(\mathrm{P}_{\mathrm{D}}\right)^{-0.86}$ & -0.860 & $\mathrm{q}_{\mathrm{s}}=3.6200\left(\mathrm{P}_{\mathrm{S}}\right)^{1.1}$ & 1.1 \\
Canada & $\mathrm{q}_{\mathrm{D}}=426499.0919\left(\mathrm{P}_{\mathrm{D}}\right)^{-0.86}$ & -0.860 & $\mathrm{q}_{\mathrm{s}}=0.0241\left(\mathrm{P}_{\mathrm{s}}\right)^{1.5}$ & 1.5 \\
Denmark & $\mathrm{q}_{\mathrm{D}}=106631.3146\left(\mathrm{P}_{\mathrm{D}}\right)^{-0.8}$ & -0.800 & $\mathrm{q}_{\mathrm{s}}=2.8600\left(\mathrm{P}_{\mathrm{S}}\right)^{0.9}$ & 0.9 \\
Mexico & $\mathrm{q}_{\mathrm{D}}=1298$ & 0.000 & $\mathrm{q}_{\mathrm{s}}=17.5918\left(\mathrm{P}_{\mathrm{S}}\right)^{0.55}$ & 0.55 \\
\hline
\end{tabular}

Sources: See above as Table 9 .

In the case of Japan ministerial order (shourei) prices are used as representative prices. The ministerial ordinance is not necessarily related to the price stabilisation band but it moves within it. It describes the mean value between the high quality and the good quality price for pork meat. In general an average is taken for the separately defined markets (Tokyo and Oosaka). And although only about 14 percent of the domestically produced pork is marketed via these two markets, they dominate the price within all over Japan. The ministerial ordinance is regarded as the mean domestic pork price for carcass, and is close to the actual annual average price of pork.

In a second step transportation costs to each market need to be calculated, as well as the insurance costs. At the present stage detailed information on real transportation costs through exporting companies is not available. However, the so-called FEFC Tariff System gives some detailed information on freight costs, which are referred to in the first 
place. Reverting to the Maersk Sealand shipment rates then completes the required data. According to these sources the following transportation costs per ton of pork can be expected.

Table 11. Transportation costs.

Unit: US\$/t

\begin{tabular}{lccccc}
\hline & Japan & United States & Canada & Denmark & Mexico \\
\hline Japan & 0.0 & 415.108 & 308.070 & 318.818 & 432.279 \\
United States & 415.108 & 0.0 & 117.430 & 240.938 & 112.139 \\
Canada & 308.070 & 117.430 & 0.0 & 265.166 & 138.794 \\
Denmark & 318.818 & 240.938 & 265.166 & 0.0 & 351.786 \\
Mexico & 432.279 & 112.139 & 138.794 & 351.786 & 0.0 \\
\hline
\end{tabular}

Sources: Calculation.

Table 12. Insurance cost per unit exported.

Unit: US\$/t

\begin{tabular}{lccccc}
\hline & Japan & United States & Canada & Denmark & Mexico \\
\hline Japan & 0.0 & 0.0 & 0.0 & 0.0 & 0.0 \\
United States & 0.0 & 0.0 & 0.0 & 0.0 & 0.0 \\
Canada & 0.0 & 0.0 & 0.0 & 0.0 & 0.0 \\
Denmark & 0.0 & 0.0 & 0.0 & 0.0 & 0.0 \\
Mexico & 0.0 & 0.0 & 0.0 & 0.0 & 0.0 \\
\hline
\end{tabular}

Source: Preliminary assumption.

Insurance costs play a role especially in the case of perishable goods. However, since pork comes in frozen or chilled, insurance costs in the first place are neglected, also due to lack of data available. Insurance premium is mainly negotiated on between importers and insurance companies in the exporting country, which makes it rather difficult to get access to these data. According to experts however, in general insurance premium are approximately 0.8 percent of the CIF price when landing.

\section{RESULTS AND DISCUSSION}

The following tables summarise the first-run-results of the model applied to the Japanese pork market under the conditions mentioned above. Table 13 reflects upon the equilibrium situation under the present condition without the safeguard being triggered in the case of linear functions. Hence, the gate-price is being kept at $393 \mathrm{Yen} / \mathrm{kg}$ carcass weight equivalent (3299.53 US\$/t).

According to the results Mexico does not export any pork to either the primary nor to the secondary market of any importing country. This may be due to the first approach assuming a fixed demand of 1298 thousand tons and a fixed supply of 1065 thousand tons for Mexico. Further, only Denmark and Canada (and Japan) supply Japan's primary market with pork, but not the U.S. In addition, Canada also exports to the U.S. and Mexico. 
Table 13. Equilibrium Solution (CIF price-based, linear) in case: $A K K=393 \mathrm{Yen} / \mathrm{kg}$ carcass, $\mathrm{ATR}=0.043$.

Unit: $1000 \mathrm{t}$ carcass; US $\$ / \mathrm{t}$

\begin{tabular}{cccccccccccc}
\hline \multicolumn{10}{c}{ Primary Market } & \multicolumn{10}{c}{ Secondary Market } \\
\hline 1179.49 & 0 & 0 & 0 & 0 & 0 & 0 & 0 & 0 & 0 & S1 $=1179.49$ & PS1 $=3299.53$ \\
0 & 8047.99 & 0 & 0 & 0 & 0 & 0 & 0 & 0 & 0 & S2 $=8280.99$ & PS2 $=1133.84$ \\
241.11 & 555.40 & 1045.28 & 0 & 233.0 & 0 & 0 & 0 & 0 & 0 & S3 $=1841.78$ & PS3 $=1083.84$ \\
1138.14 & 0 & 0 & 389.85 & 0 & 0 & 0 & 0 & 0 & 0 & S4 $=1527.99$ & PS4 $=1073.09$ \\
0 & 0 & 0 & 0 & 1065.0 & 0 & 0 & 0 & 0 & 0 & S5 $=1065$ & PS5 $=1183.84$ \\
\hline 2558.73 & 8603.39 & 1045.28 & 389.85 & 1298.0 & 0 & 0 & 0 & 0 & 0 & Total 13895.25 & \\
\hline
\end{tabular}

$\begin{array}{lll}\text { D1 }=2558.73 & \text { SP1 }=0 & \text { PD1 }=3299.53 \\ \text { D2 }=8603.39 & \text { SP2 }=0 & \text { PD2 }=1133.84 \\ \text { D3 }=1045.28 & \text { SP3 }=0 & \text { PD3 }=1083.84 \\ \text { D4 }=389.85 & \text { SP4 }=0 & \text { PD4 }=1073.09 \\ \text { D5 }=1298.00 & \text { SP5 }=0 & \text { PD5 }=1183.84\end{array}$

Obviously markets would rather supply their own domestic markets than export. This could hint at too high-evaluated transportation costs. Besides, as we can neglect the tariff-quota system in this research study, the secondary market can be practically disregarded.

For comparative analysis, the following Table 14 displays the equilibrium situation in the case of exponential functions. It is obvious, that the results differ from the previous ones above in that they reflect more realistically on the exports of pork to Japan. The total traded volume is slightly higher than in the case of linear functions. As far as market prices are concerned, the linear functions reflect more realistically on the price ranges between the three NAFTA pork exporters, the U.S., Canada and Mexico.

Table 14. Equilibrium Solution (CIF price-based, non-linear) in case: $A K K=393$ Yen/kg carcass, $A T R=0.043$. Unit: 1000 t carcass; US $\$ / \mathrm{t}$

\begin{tabular}{ccccccccccccc}
\hline \multicolumn{10}{c}{ Primary Market } & \multicolumn{10}{c}{ Secondary Market } \\
\hline 1180.2972 & 0 & 0 & 0 & 0 & 0 & 0 & 0 & 0 & 0 & S1 $=1180.30$ & PS1 $=3299.53$ \\
451.9690 & 8152.1918 & 0 & 0 & 0 & 0 & 0 & 0 & 0 & 0 & S2 $=8604.16$ & PS2 $=1172.44$ \\
38.2304 & 0 & 960.6333 & 0 & 0 & 0 & 0 & 0 & 0 & 0 & S3 $=998.86$ & PS3 $=1197.64$ \\
962.9459 & 0 & 0 & 434.2651 & 0 & 0 & 0 & 0 & 0 & 0 & S4 $=1397.21$ & PS4 $=971.998$ \\
0 & 213.3382 & 0 & 0 & 1298 & 0 & 0 & 0 & 0 & 0 & S5 $=1511.34$ & PS5 $=1060.30$ \\
\hline 2633.44 & 8365.53 & 960.63 & 434.27 & 1298.00 & 0 & 0 & 0 & 0 & 0 & Total 13691.87 & \\
\hline D1 $=2633.44$ & SP1 $=0$ & PD1 $=3299.53$ & & & & & \\
D2 $=8365.53$ & SP2 $=0$ & PD2 $=1172.44$ & & & & & & \\
D3 $=960.63$ & SP3 $=0$ & PD3 $=1197.64$ & & & & & & \\
D4 $=434.27$ & SP4 $=0$ & PD4 $=971.99$ & & & & & \\
D5 $=1298.00$ & SP5 $=0$ & PD5 $=1060.30$ & & & & &
\end{tabular}

The following Table 15 summarises the results in case the safeguard was triggered resulting in a gate-price of $482 \mathrm{Yen} / \mathrm{kg}$ carcass weight equivalent ( $4048.80 \mathrm{US} \$ / \mathrm{t}$ ). The ad valorem tariff is kept at $4.3 \%$. The main difference to the previous situation (Table 13) without the safeguard is a decrease of the Japanese demand and an increase in price. 
Whereas Japan provides a higher share of its demand by domestic production, Denmark provides only less than $1 / 2$ of its previous amount. Canada at the same time is not supplying any pork under the condition of the safeguard being triggered. Consequently, it shifts its produced volume to its domestic market and the U.S.

Table 15. Equilibrium Solution (CIF price-based, linear) in case: $A K K=482 \mathrm{Yen} / \mathrm{kg}$ carcass, $\mathrm{ATR}=0.043$.

Unit: 1000 t carcass; US\$/t

\begin{tabular}{cccccccccccc}
\hline \multicolumn{10}{c}{ Secondary Market } \\
\hline 1399.78 & 0 & 0 & 0 & 0 & 0 & 0 & 0 & 0 & 0 & S1 $=1399.78$ & PS1 $=4048.80$ \\
0 & 7901.89 & 0 & 0 & 0 & 0 & 0 & 0 & 0 & 0 & S2 $=8134.89$ & PS2 $=1115.74$ \\
0 & 734.98 & 1061.59 & 0 & 233.0 & 0 & 0 & 0 & 0 & 0 & S3 $=1796.57$ & PS3 $=1065.74$ \\
769.25 & 78.11 & 0 & 429.90 & 0 & 0 & 0 & 0 & 0 & 0 & S4 $=1277.35$ & PS4 $=874.80$ \\
0 & 0 & 0 & 0 & 1065.0 & 0 & 0 & 0 & 0 & 0 & S5 $=1065$ & PS5 $=1165.74$ \\
\hline 2169.11 & 8714.98 & 1061.59 & 429.90 & 1298 & 0 & 0 & 0 & 0 & 0 & Total 13673.59 & \\
\hline D1 $=2169.11$ & SP1 $=0$ & PD1 $=4048.80$ & & & & & \\
D2 $=8714.98$ & SP2 $=0$ & PD2 $=1115.74$ & & & & & \\
D3 $=1061.59$ & SP3 $=0$ & PD3 $=1065.74$ & & & & & \\
D4 $=429.90$ & SP4 $=0$ & PD4 $=874.80$ & & & & & \\
D5 $=1298.00$ & SP5 $=0$ & PD5 $=1165.74$ & & & &
\end{tabular}

Table 16. Equilibrium Solution (CIF price-based, linear) in case: $A K K=0$ Yen $/ \mathrm{kg}$ carcass, $A T R=0.043$.

Unit: 1000 t carcass; US $\$ / t$

\begin{tabular}{cccccccccccc}
\hline \multicolumn{10}{c}{ Primary Market } & \multicolumn{10}{c}{ Secondary Market } \\
\hline 681.25 & 0 & 0 & 0 & 0 & 0 & 0 & 0 & 0 & 0 & $\mathrm{~S} 1=681.25$ & PS1 $=1604.84$ \\
0 & 8315.14 & 110.23 & 0 & & 0 & 0 & 0 & 0 & 0 & $\mathrm{~S} 2=8658.37$ & PS2 $=1180.60$ \\
1405.43 & 0 & 802.82 & 0 & 233.0 & 0 & 0 & 0 & 0 & 0 & $\mathrm{~S} 3=2208.25$ & PS3 $=1230.60$ \\
1353.30 & 0 & 0 & 360.20 & 0 & 0 & 0 & 0 & 0 & 0 & S4 $=1713.50$ & PS4 $=1219.86$ \\
0 & 0 & 0 & 0 & 1065.0 & 0 & 0 & 0 & 0 & 0 & S5 $=1065$ & PS5 $=1230.60$ \\
\hline 3439.98 & 8315.14 & 913.05 & 360.20 & 1298 & 0 & 0 & 0 & 0 & 0 & Total 14326.37 \\
\hline
\end{tabular}

$\begin{array}{lll}\text { D1 }=3439.98 & \text { SP1 }=0 & \text { PD1 }=1604.84 \\ \text { D2 }=8315.14 & \text { SP2 }=0 & \text { PD2 }=1180.60 \\ \text { D3 }=913.05 & \text { SP3 }=0 & \text { PD3 }=1230.60 \\ \text { D4 }=360.20 & \text { SP4 }=0 & \text { PD4 }=1219.86 \\ \text { D5 }=1298.00 & \text { SP5 }=0 & \text { PD5 }=1230.60\end{array}$

Table 16 below shows the equilibrium situation in case there was no gate-price at all. As a result, Canada and Denmark supply a higher volume of pork to the Japanese market. However, the major change to the original situation occurs at the Canadian export market. A complete shift from exports originally (Table 13) destined for the U.S. market to the Japanese market is most evident. However, the total quantity traded also increases. Japan would only approximately supply one fifth of its domestic demand. Further, market price would also decrease by more than 50 percent.

Changes in the distribution of exports become even more obvious -as shown in Table 17 above - in the case of non-linear exponential functions. Compared to the previous 
situation in Table 14 Mexico is now also supplying its share to the Japanese market, which was originally destined for the U.S. market under the gate-price system.

In a next step, the ad valorem tariff is being eliminated, while the gate-price remains unchanged at $383 \mathrm{Yen} / \mathrm{kg}$ carcass weight equivalent.

Table 17. Equilibrium Solution (CIF price-based, non-linear) in case: $\mathrm{AKK}=0$ Yen $/ \mathrm{kg}$ carcass, $\mathrm{ATR}=0.043$. Unit: 1000 t carcass; US $\$ / t$

\begin{tabular}{rccccccccccc}
\hline \multicolumn{10}{c}{ Primary Market } \\
\hline 704.98 & 0 & 0 & 0 & 0 & 0 & 0 & 0 & 0 & 0 & S1 $=704.98$ & PS1 $=1773.35$ \\
1787.57 & 7730.57 & 0 & 0 & 0 & 0 & 0 & 0 & 0 & 0 & S2 $=9518.14$ & PS2 $=1285.14$ \\
407.87 & 0 & 843.99 & 0 & 0 & 0 & 0 & 0 & 0 & 0 & S3 $=1256.86$ & PS3 $=1392.17$ \\
1589.36 & 0 & 0 & 327.81 & 0 & 0 & 0 & 0 & 0 & 0 & S4 $=1917.17$ & PS4 $=1381.43$ \\
260.23 & 0 & 0 & 0 & 1298.0 & 0 & 0 & 0 & 0 & 0 & S5 $=1558.23$ & PS5 $=1267.97$ \\
\hline 4750.02 & 7730.57 & 843.99 & 327.81 & 1298 & 0 & 0 & 0 & 0 & 0 & Total 14955.38 \\
\hline D1 $=4750.02$ & SP1 $=0$ & PD1 $=1773.35$ & & & & & \\
D2 $=7730.57$ & SP2 $=0$ & PD2 $=1285.14$ & & & & & \\
D3 $=843.99$ & SP3 $=0$ & PD3 $=1392.17$ & & & & & \\
D4 $=327.81$ & SP4 $=0$ & PD4 $=1381.43$ & & & & & \\
D5 $=1298.00$ & SP5 $=0$ & PD5 $=1267.97$ & & & &
\end{tabular}

Table 18. Equilibrium Solution (CIF price-based, linear) in case: $A K K=393 \mathrm{Yen} / \mathrm{kg}$ carcass, $\mathrm{ATR}=0.0$. Unit: $1000 \mathrm{t}$ carcass; US $\$ / \mathrm{t}$

\begin{tabular}{cccccccccccc}
\hline \multicolumn{1}{c}{ Primary Market } & \multicolumn{10}{c}{ Secondary Market } \\
\hline 11793.49 & 0 & 0 & 0 & 0 & 0 & 0 & 0 & 0 & 0 & S1 $=1179.49$ & PS1 $=3299.53$ \\
0 & 8047.99 & 0 & 0 & 233.00 & 0 & 0 & 0 & 0 & 0 & S2 $=8280.99$ & PS2 $=1133.84$ \\
241.11 & 555.40 & 1045.28 & 0 & 0 & 0 & 0 & 0 & 0 & 0 & S3 $=1841.78$ & PS3 $=1083.84$ \\
1138.14 & 0 & 0 & 389.85 & 0 & 0 & 0 & 0 & 0 & 0 & S4 $=1527.99$ & PS4 $=1073.09$ \\
0 & 0 & 0 & 0 & 1065.0 & 0 & 0 & 0 & 0 & 0 & S5 $=1065$ & PS5 $=1183.84$ \\
\hline 2558.73 & 8603.39 & 1045.28 & 389.85 & 1298 & 0 & 0 & 0 & 0 & 0 & Total 13865.25 & \\
\hline D1 $=2558.73$ & SP1 $=0$ & PD1 $=3299.53$ & & & & & \\
D2 $=8603.39$ & SP2 $=0$ & PD2 $=1133.84$ & & & & \\
D3 $=1045.28$ & SP3 $=0$ & PD3 $=1083.84$ & & & & \\
D4 $=389.85$ & SP4 $=0$ & PD4 $=1073.09$ & & & & \\
D5 $=1298.00$ & SP5 $=0$ & PD5 $=1183.84$ & & & &
\end{tabular}

In fact, the results are exactly the same as in the case of a $4.3 \%$ ad valorem tariff as shown in Table 13 above. An elimination of the low ad valorem tariff rate would hence not change the equilibrium situation, as it would occur in the present situation according to this model.

Finally, Tables 19 and 20 present the equilibrium results in case of no ad valorem tariff and no gate-price were applied for the case of linear and exponential functions. In the case of linear functions the equilibrium solutions does not differ from the equilibrium solutions of the case when the safeguard has been abolished (Table 16). In the case of 
exponential functions, however, the differences are of minor significance (Table 17). Again, the neglect of the small ad valorem tariff of $4.3 \%$ does not make any (or major) difference.

Table 19. Equilibrium Solution (CIF price-based, linear) in case: $A K K=0$ Yen $/ \mathrm{kg}$ carcass, $A T R=0.0$.

Unit: $1000 \mathrm{t}$ carcass; US $\$ / \mathrm{t}$

\begin{tabular}{cccccccccccc}
\hline \multicolumn{11}{c}{ Primary Market } & \multicolumn{11}{c}{ Secondary Market } \\
\hline 662.60 & 0 & 0 & 0 & 0 & 0 & 0 & 0 & 0 & 0 & $\mathrm{~S} 1=662.60$ & PS1 $=1541.38$ \\
0 & 8298.47 & 148.73 & 0 & 0 & 0 & 0 & 0 & 0 & 0 & $\mathrm{~S} 2=8680.20$ & PS2 $=1183.31$ \\
1453.12 & 0 & 761.88 & 0 & 233.0 & 0 & 0 & 0 & 0 & 0 & $\mathrm{~S} 3=2215.00$ & PS3 $=1233.31$ \\
1357.26 & 0 & 0 & 359.65 & 0 & 0 & 0 & 0 & 0 & 0 & $\mathrm{~S} 4=1716.92$ & PS4 $=1222.56$ \\
0 & 0 & 0 & 0 & 1065.0 & 0 & 0 & 0 & 0 & 0 & S5 $=1065$ & PS5 $=1233.31$ \\
\hline 3472.97 & 8298.47 & 910.61 & 359.65 & 1298 & 0 & 0 & 0 & 0 & 0 & Total 14339.70 & \\
\hline D1 $=3472.97$ & SP1 $=0$ & PD1 $=1541.38$ & & & & & & \\
D2 $=8298.47$ & SP2 $=0$ & PD2 $=1183.31$ & & & & & \\
D3 $=910.61$ & SP3 $=0$ & PD3 $=1233.31$ & & & & & \\
D4 $=359.65$ & SP4=0 & PD4 $=1222.56$ & & & & & \\
D5 $=1298.0$ & SP5 $=0$ & PD5 $=1233.31$ & & & & & & &
\end{tabular}

Table 20. Equilibrium Solution (CIF price-based, non-linear) in case: $A K K=0$ Yen $/ \mathrm{kg}$ carcass, $A T R=0.0$.

Unit: $1000 \mathrm{t}$ carcass; US $\$ / \mathrm{t}$

\begin{tabular}{rcccccccccccc}
\hline \multicolumn{1}{c}{ Primary Market } & \multicolumn{11}{c}{ Secondary Market } \\
\hline 684.42 & 0 & 0 & 0 & 0 & 0 & 0 & 0 & 0 & 0 & $\mathrm{~S} 1=684.42$ & PS1 $=1711.22$ \\
1933.32 & 7674.26 & 0 & 0 & 0 & 0 & 0 & 0 & 0 & 0 & $\mathrm{~S} 2=9607.58$ & PS2 $=1296.11$ \\
428.38 & 0 & 838.31 & 0 & 0 & 0 & 0 & 0 & 0 & 0 & $\mathrm{~S} 3=1266.69$ & PS3 $=1403.15$ \\
1605.13 & 0 & 0 & 325.74 & 0 & 0 & 0 & 0 & 0 & 0 & S4 $=1930.87$ & PS4 $=1392.40$ \\
262.49 & 0 & 0 & 0 & 1298 & 0 & 0 & 0 & 0 & 0 & S5 $=1560.49$ & PS5 $=1278.94$ \\
\hline 4913.73 & 7674.26 & 838.31 & 325.74 & 1298 & 0 & 0 & 0 & 0 & 0 & Total 15050.04 & \\
\hline D1 $=4913.73$ & SP1 $=0$ & PD1 $=1711.22$ & & & & & & \\
D2 $=7674.26$ & SP2 $=0$ & PD2 $=1296.11$ & & & & & & \\
D3 $=838.31$ & SP3 $=0$ & PD3 $=1403.15$ & & & & & \\
D4 $=325.74$ & SP4 $=0$ & PD4 $=1392.40$ & & & & & & \\
D5 $=1298.0$ & SP5 $=0$ & PD5 $=1278.94$ & & & & & & &
\end{tabular}

\section{CONCLUSION AND PROBLEMS TO BE SOLVED IN THE FUTURE}

The Japanese gate-price system is a rather complicated differential tariff system. In addition to its impact as a variable levy, it has an even more relevant impact when considering its welfare effect. Since pork is basically imported in cuts, importers tend to bring high value cuts in order to meet the gate-price and by that avoid paying an extra tariff. Consequently pork cuts, which are not necessarily demanded, are imported and sold at relatively low price. However, although countries such as Denmark emphasise on the disadvantaged treatment for pork, which comes in frozen and hence has a lower price, which again makes it difficult to meet the gate-price, pork exports to Japan still prove to be 
profitable. The reason being, those pork prices in Japan are rather high compared to other export markets.

The model applied in this paper is one of the first approaches to deal with the gate-price as a variable levy in general. Former studies such as the ERS ${ }^{6}$ model have already dealt with this issue by equating a fixed artificial ad valorem tariff with the gate-price system and by that simulating an effective tariff. However, using a higher effective tariff involves making assumptions that may not be valid. As an alternative, this model incorporates the gate-price as an endogenous variable depending on the CIF price of the pork imported. By that it avoids making assumptions, which might not be appropriate. Nevertheless, it neglects the fact-as mentioned above- that the gate-price affects varying pork parts differently. On the other hand, being specifically developed for the Japanese market, this model lives up to the expectations that it suits the Japanese tariff system. With respect to a future negotiation on opening the agricultural markets of Japan, one should consider not only to evaluate the outcome of international standard models itself but also learn about the methodologies applied in the country concerned.

In addition to the difficulties for measuring the gate-price as mentioned above, it should be noted here that the international pork market itself is a highly fluctuating market, eventually also because of the occurrence of BSE and the hoof-and-mouth disease. It is hence very difficult to trace a reliable supply and demand function based on recently estimated elasticities. Consequently, any assumptions made have to be long-run presumptions.

Further, this research has assumed that demand and supply functions are linear (alternatively exponential) functions merely dependent on own price. Hence, they only incorporate own-price elasticities. However, the model applied above allows for the further integration of more elaborate demand and supply functions, although it has not yet been extended to that level in practice. This shall be among the further steps of this research in order to approximate a realistic situation.

However, in the first step it becomes clear that the impact of the gate-price is much more effective -or relevant- than the simple ad-valorem tariff. The abolition of the gate-price system has underlined this in the case of both, linear and exponential functions. However, apart from that, results vary significantly according to the functions chosen in this research. While under the assumption of linear functions, exporters of pork to Japan only include Denmark and Canada, the case of exponential function also introduces the U.S. as a major exporter. The absence of the U.S. in the case of linear functions might be due on the one hand to the over-estimated price-elasticity used. However, by adjusting transportation cost in the case of the U.S. the solution changes slightly. This might suggest that transportation costs between the U.S., Canada and Mexico are much lower than assumed. In fact, it is even more realistic to assume transportation between these three NAFTA states by truck rather than by ship. However, under first-approach assumption of a fixed demand and supply, Mexico seems not to be competitive in either case. Only under an abolition of the gate-price in the case of exponential functions can it export to the Japanese pork market.

The absence of the U.S. in the case of linear functions as a major exporter to the

${ }_{6}$ The Economic Research Service Model of the United States Department of Agriculture (USDA) 
Japanese market is the major "failure" of the example presented in this model. In order to adjust it to the realistic situation, further detailed research needs to be conducted with emphasis on the domestic pork markets of each country involved. However, this paper has in the first place put its predominance on the Japanese pork market. Yet, it neglected the peculiar character of the Japanese market and distribution system, which due to service charges at each active element of the distribution chain actually causes the high prices for imported feed. A consideration of the various marketing routes has already been suggested by KAWAGUCHI (2003b). Moreover, this research has assumed perfectly competitive markets. In reality this is not the case. For instance, while the U.S. is exporting pork to Japan it is also importing pork from Canada. These indirect trade routes have to be examined more closely for further adjustment.

Further detailed information also needs to be inquired in the case of the European Union (EU) as one entity. Although Denmark is being the major pork supplier to the Japanese market, internal EU policies, especially with consideration to the EU enlargement, play a further interesting role. At present, for instance, it seems that Denmark places further export interests in the accessing countries. However apart from that, pork produced in Denmark is also influenced by the regulations of the CAP (Common Agricultural Policy). With the EU providing export subsidies for pork in various cases and guaranteeing storage aid in cases when EU pork prices fall, this might also support Danish pork export and make it more competitive. On the other hand, environmental restrictions set by the CAP also have to be taken into account.

However, in order to reflect on a realistic international pork trade situation, this research shall be extended in the near future by focusing on the EU market more detailed. Finally, the enlargement of the EU shall also be taken into consideration.

\section{REFERENCES}

Enke, S. 1951 Equilibrium Among Spatially Separated Markets: Solution by Electric Analogue. Econometrica, 19(1): 40-47

Kano, H. and T. Kawaguchi 2004a Introduction of Differential Tariff to Spatial Equilibrium Model of International Trade under Tariff Quota System with Specific and Ad Valorem Duties: Theoretical Study - The Case of Perfectly Competitive International Trade -. Sci. Bull. Fac. Agr., Kyushu Univ., 59(1): 63-70 (in Japanese)

Kano, H. and T. Kawaguchi 2004b Introduction of Differential Tariff to Spatial Equilibrium Model of International Trade under Tariff Quota System with Specific and Ad Valorem Duties: Example Study - The Case of Perfectly Competitive International Trade -. Sci. Bull. Fac. Agr., Kyushu Univ., 59(1): 71-75 (in Japanese)

Kano, H. and T. Kawaguchi 2004c Introduction of Differential Tariff to Spatial Equilibrium Model of International Trade under tariff Quota system with specific and ad valorem Duties - The Case of Oligopolistic International Trade -. Sci. Bull. Fac. Agr., Kyushu Univ., 59(1): 77-87 (in Japanese)

Kawaguchi, T. 2003a On the Direction of Development of Spatial Equilibrium Model in Recent Years. Sci. Bull. Fac. Agr., Kyushu Univ., 57(2): 261-272 (in Japanese)

Kawaguchi, T. 2003b Studies on Spatial Equilibrium Model of International Trade by Profit-making Traders under Tariff Quota System with Specific and Ad valorem Duties. Sci. Bull. Fac. Agr., Kyushu Univ., 57(2): 273-282 (in Japanese)

Kawaguchi, T. and C. Shono 2000 On the Existence of a Solution to Linear Complementarity Problem in Spatial Equilibrium Model of International Trade and its Algorithm. Sci. Bull. Fac. Agr., Kyushu Univ., 55(1): 77-81 (in Japanese)

Nagurney, A. 1993 Network economics: A Variational Inequality Approach. Kluwer Academic 
Publisher, Boston

Ohga, K. and K. Yanagishima 1995 IFPSIM International Food and Agricultural Policy Simulation Model (User's Guide), JIRCAS, MAFF

Samuelson, P. A. 1952 Spatial Price Equilibrium and Linear Programming. The American Economic Review, 42: 283-303

Shono, C. and T. Kawaguchi 1999a Studies on Spatial Equilibrium Model of International Trade under Tariff Quota System with Specific and Ad Valorem Duties - The Case of Perfectly Competitive International Trade-. Sci. Bull. Fac. Agr., Kyushu Univ., 53(1-4): 79-88 (in Japanese)

Shono, C. and T. Kawaguchi 1999b Studies on Spatial Equilibrium Model of International Trade under Tariff Quota System with Specific and Ad Valorem Duties - The Case of Oligopolistic International Trade -. Sci. Bull. Fac. Agr., Kyushu Univ., 54(1·2): 85-96 (in Japanese)

Shono, C. and T. Kawaguchi 2000 Introduction of Export Quota and Minimum Export Prices to Spatial Equilibrium Model of International Trade under Tariff Quota System with Specific and Ad Valorem Duties - The Case of Perfectly Competitive and Oligopolistic International Trade -. Sci. Bull. Fac. Agr., Kyushu Univ., 54(3·4): 157-170 (in Japanese)

Shono, C., T. Kawaguchi and N. Suzuki 2001 Introduction of Export Subsidies to Spatial Equilibrium Model of International Trade under Tariff Quota System with Specific and Ad valorem Duties and its Application to International Dairy Products Market - The Case of Perfectly Competitive International Trade -. Sci. Bull. Fac. Agr., Kyushu Univ., 55(2): 259-296 (in Japanese)

Takayama, T. and G. G. Judge 1964a Equilibrium Among Spatially Separated Markets: A Reformulation. Econometrica, 32(4): 510-524

Takayama, T. and G. G. Judge 1964b Spatial Equilibrium and Quadratic Programming. Journal of Farm Economics, 46: 67-93

Takayama, T. and G. G. Judge 1971 Spatial and Temporal Price and Allocation Models. North-Holland Publishing Company, Amsterdam 